\title{
„Krakowskie ślady Marszałka Józefa Pilsudskiego. 150. rocznica urodzin”- wystawa w Bibliotece Glównej Akademii Górniczo-Hutniczej w Krakowie, współorganizowana przez Archiwum Narodowe w Krakowie
}

13 listopada 2017 r. w Bibliotece Głównej Akademii Górniczo-Hutniczej w Krakowie odbył się wernisaż wystawy „Krakowskie ślady Marszałka Józefa Piłsudskiego. 150. rocznica urodzin". Uroczystego otwarcia ekspozycji dokonali prof. Tadeusz Słomka, rektor AGH, prof. Andrzej Pach, prorektor AGH ds. nauki, dr hab. Wojciech Krawczuk, dyrektor Archiwum Narodowego w Krakowie i mgr Ewa Dobrzańska-Lankosz, dyrektor Biblioteki Głównej AGH. Wystawa została przygotowana z okazji przypadającej 5 grudnia 150. rocznicy urodzin Józefa Piłsudskiego. Wernisaż uświetniła swą obecnością delegacja Krakowskiego Szwadronu Ułanów im. Józefa Piłsudskiego z dowódcą rotmistrzem Henrykiem Bugajskim na czele i najsłynniejszym kawalerzystą Włodzimierzem Wową Brodeckim oraz historycy-krakowianiści Janusz T. Nowak i Witold Turdza. Otwarcie wystawy zyskało dodatkową oprawę artystyczną. Po oficjalnych przemówieniach, pieśni legionowe wykonała znana krakowska artystka Wiktoria Bisztyga. Przepięknie i nastrojowo zabrzmiały „O mój rozmarynie” i „Rozkwitały pąki białych róż”, a w wykonanie tej ostatniej pieśni ochoczo włączyli się wszyscy zebrani.

Józef Piłsudski należy do największych postaci w dziejach Polski. Mimo że urodził się na Wileńszczyźnie, to przez wiele lat życia związany był z Krakowem. Z woli całego narodu Jego ciało spoczęło na Wawelu, obok grobów królewskich, kryjących szczątki dawnych władców Rzeczypospolitej. Składając ciało Pierwszego Marszałka Polski na Wawelu w Krakowie, naród nie tylko spełnił wolę zmarłego, lecz na zawsze połączył pamięć o Nim z miastem, z którym związanych było szereg pierwszorzędnej wagi wydarzeń z życia Piłsudskiego i które On szczególnie wśród innych miast wyróżniał.

Trudno przecenić wagę związków Józefa Piłsudskiego z Krakowem. Tutaj podjął decyzję o organizacji Strzelców i wymarszu z I Kompanią Kadrową, to miasto odwiedził jako pierwsze po przejęciu władzy w 1918 r., tutaj po latach znalazł miejsce wiecznego spoczynku. W Krakowie posiada też najbardziej oryginalny pomnik - Kopiec Piłsudskiego. Śladów obecności Marszałka w Krakowie jest wiele. Są to miejsca, w których bywał prywatnie i oficjalnie, oraz uroczystości, w których brał udział. Wiele z nich jest upamiętnionych poprzez tablice, obiekty i instytucje noszące Jego imię. Tak jak mówi tytuł wystawy, te ślady zaprezentowane zostały w grupach tematycznych, m.in.: miejsca zamieszkania, Rynek Główny, Wawel, Oleandry, Uniwersytet Jagielloński, Błonia, Kopiec, Szkoły, Ulica J. Piłsudskiego, Imieniny, Honorowy Obywatel Krakowa, Pogrzeb i Akademia Górniczo-Hutnicza.

Przygotowanie tak bogatej tematycznie, z taką ilością eksponatów, wystawy nie byłoby możliwe, gdyby nie życzliwość i bezinteresowna pomoc kilku osób i instytucji, które 
udostępniły swoje zbiory, w niektórych wypadkach pamiątki rodzinne. Prezentowane eksponaty pochodzą ze zbiorów: Władysława Andreasika, Wiktora Cygana, Zygmunta Czarneckiego, Jerzego Dudy, Andrzeja Gruszeckiego, Barbary Janczak, Jana Krzyżanowskiego, Stanisława Malika, Oli Maurer, Bogdana Micka, Małgorzaty Musiał, Macieja Rudego, Hieronima Sieńskiego, Piotra Siły, Zbigniewa Sulimy, Łukasza Święcha i Ewy Wnukowej oraz instytucji: Archiwum Narodowego w Krakowie, Centralnej Biblioteki Wojskowej im. Marszałka Józefa Piłsudskiego, Fundacji Centrum Dokumentacji Czynu Niepodległościowego, Miejskiego Domu Kultury w Mińsku Mazowieckim, Muzeum AGH, Muzeum Historycznego Miasta Krakowa i Biblioteki Głównej AGH. Ekspozycja została przygotowana przez pracowników Oddziału Informacji Naukowej Biblioteki Głównej AGH pod kierunkiem kustosza Hieronima Sieńskiego.

Z powodu wagi i znaczenia posiadanych dokumentów do współorganizowania ekspozycji zostało zaproszone Archiwum Narodowe w Krakowie. Współpraca ta nie była przypadkowa. Chciano zaznaczyć, jak bardzo ciekawą część zasobu Archiwum stanowią, gromadzone od lat 20. XX w., dokumenty związane z działalnością Legionów Polskich uzupełnione o zbiory biblioteczne; liczące niemal 1000 jednostek akta Naczelnego Komitetu Narodowego w Krakowie z lat 1914-1920, zbiory fotografii, afiszy i plakatów. Bogato prezentują się materiały archiwalne pochodzące z okresu międzywojennego dotyczące obchodów rocznic niepodległościowych oraz wydarzeń związanych z postacią Marszałka. Materiały te należą do najważniejszych na prezentowanej wystawie, znacznie podnosząc jej wartość merytoryczną.

W tematykę wystawy wprowadza specjalnie opracowane „Krakowskie kalendarium Józefa Piłsudskiego" przedstawiające najistotniejsze daty z życia Marszałka związane z Krakowem. Po raz pierwszy przebywał tutaj w sierpniu $1896 \mathrm{r}$.

Marszałek wielokrotnie uczestniczył w oficjalnych uroczystościach, które odbywały się na Rynku Głównym. W działach obrazujących miejsca zamieszkania i uroczystości na Rynku dominują fotografie i książki, w tym kilka autorstwa Janusza T. Nowaka, znawcy tematyki piłsudczykowskiej.

Niezwykle interesująco przedstawia się dział zatytułowany „Oleandry”. Jest to kultowe miejsce dla miłośników historii i zarazem symbol. Stąd 6 sierpnia w 1914 r. o godzinie 3.30 wyruszyła sformowana przez Józefa Piłsudskiego I Kompania Kadrowa, będąca pierwszym regularnym oddziałem stanowiącym podwaliny odradzającego się Wojska Polskiego. W 10. rocznicę wymarszu I Kompanii Kadrowej - w 1924 r. - odbył się Marsz jej Szlakiem. Po odzyskaniu niepodległości dawni legioniści postanowili upamiętnić to miejsce. Tak pojawiła się inicjatywa powstania Domu im. Józefa Piłsudskiego. W dniu 11 listopada 1928 r. położono kamień węgielny pod budowę Domu. 6 sierpnia 1934 r., w 20. rocznicę wymarszu I Kompanii Kadrowej, odbyło się poświęcenie pierwszego skrzydła kompleksu. Wydarzenia te obrazują dokumenty i plany związane z budową i urządzeniem domu im. J. Piłsudskiego.

Prezentowany jest również unikatowy dodatek do „Ilustrowanego Kuriera Codziennego" z 6 sierpnia 1934 r. wydany w 20-lecie wymarszu I Kompanii Kadrowej oraz niecodzienny żakardowy portret Marszałka wykonany w 10-lecie wymarszu, uwagę przykuwa też maszynka do golenia będąca na wyposażeniu żołnierzy Kadrówki. 
Jednym z widocznych przejawów więzi łączącej Marszałka z Krakowem było nadanie Józefowi Piłsudskiemu honorowego obywatelstwa miasta. To wydarzenie miało miejsce 3 października 1933 r. na XXX posiedzeniu Rady Miasta Krakowa. Prezydent Krakowa Mieczysław Kaplicki powiedział wówczas: „Miasto Kraków spełnia swój obowiązek wobec największego Polaka doby współczesnej”. Wydarzenie to obrazuje prezentowany rękopis protokołu i uchwały Rady Miasta XVIII Kadencji w sprawie przyznania honorowego obywatelstwa miasta Krakowa Józefowi Piłsudskiemu.

Związki Marszałka z Uniwersytetem Jagiellońskim, który 12 marca 1920 r. przyznał $\mathrm{Mu}$ doktorat honoris causa obrazują unikatowe i mało znane fotografie. Pamięć o Marszałku utrwalają również tablice, popiersia i fresk, na które można natrafić, spacerując po mieście. Miejsca te również zostały zaprezentowane.

Spacerując po Błoniach, nie zdajemy sobie sprawy, że również i to miejsce jest związane z Marszałkiem. 6 października 1933 r., w 250. rocznicę odsieczy wiedeńskiej, odbyła się tam wyjątkowa rewia kawalerii, którą odbierał Marszałek Józef Piłsudski. Na pamiątkę tego wydarzenia na skraju Błoń przy ul. Focha umieszczono pamiątkowy kamień granitowy. Odsłonięcie głazu nastąpiło 12 maja 1936 r., czyli w pierwszą rocznicę zgonu Marszałka.

Idąc z Rynku Głównego w kierunku Błoń, nie sposób nie zauważyć, że podążamy ulicą imienia Józefa Piłsudskiego. Nazwę tę otrzymała w 1933 r., niestety po II wojnie światowej zmieniono ją. Przywrócono ją w 1990 r., a 15 sierpnia 1996 r. w Święto Żołnierza nastąpiło uroczyste odsłonięcie tablicy poświęconej Patronowi. Jest ona rekonstrukcją tablicy z 1934 r. Ponadto przy tej ulicy znajduje się jeszcze jedna tablica związana z Marszałkiem, ufundowana w 70. rocznicę Bitwy Warszawskiej oraz pomnik. Pomnik Józefa Piłsudskiego odsłonięty został 10 listopada 2008 r. Wydarzenia te obrazują książki, czasopisma i fotografie. Równie mało znane fotografie dokumentują oficjalne wizyty Józefa Piłsudskiego na Wawelu.

Miejscem najbardziej kojarzącym się z Marszałkiem (na wzgórzu zamkowym) jest krypta pod wieżą Srebrnych Dzwonów, gdzie został pochowany. Pogrzeb Józefa Piłsudskiego w Krakowie - 18 maja 1935 r. - był największą tego rodzaju uroczystością, jaka kiedykolwiek odbyła się w Polsce. Wydarzenia związane z pogrzebem ilustrują przedwojenne wydania gazet i obwieszczenia o przebiegu ceremonii. Prawdziwy rarytas stanowią tutaj zdjęcia z pogrzebu wykonane przez Andrzeja Krzyżanowskiego, które są prezentowane po raz pierwszy.

Równie interesująco wyglądają eksponaty związane z Kopcem Józefa Piłsudskiego. Przede wszystkim uwage przykuwa skrzynka służąca niegdyś do przewożenia ziemi z pól bitew oraz symboliczna łopatka, na której widnieje wizerunek kopca i napis „1936 Budowa kopca Józefa Piłsudskiego. Kraków Sowiniec”. Wyeksponowana również została statuetka kopca z popiersiem Patrona, zaprojektowana przez prof. Bronisława Chromego, będąca wyróżnieniem dla osób szczególnie zasłużonych dla dzielnicy Zwierzyniec.

Zaprezentowane także zostały zbiory filatelistyczne i numizmaty związane z Marszałkiem. Koniecznie należy podkreślić, że specjalnie na tę ekspozycję przygotowana została limitowana edycja okolicznościowego znaczka i karty pocztowej. Zadania tego podjął się znany filatelista Władysław Andreasik. Na ekspozycji pokazano ponadto kilka portretów Marszałka, medalion z brązu, popiersia z brązu oraz jedno z piaskowca, exlibris Józefa 
Piłsudskiego - jest to drzeworyt autorstwa Stanisława Ostoi-Chrostowskiego. Tematów jest jeszcze wiele, choćby obiekty i stowarzyszenia noszące Jego imię: most im. Marszałka Józefa Piłsudskiego, stadion Cracovii im. Józefa Piłsudskiego, cztery szkoły i Krakowski Szwadron Ułanów im. Józefa Piłsudskiego.

Wystawa prezentowana była do 31 stycznia 2018 r. w Bibliotece Głównej AGH i co trzeba z satysfakcją podkreślić, cieszyła się ogromnym zainteresowaniem.

Lilianna Pochwalska Archiwum Narodowe w Krakowie

Hieronim Sieński

AGH Akademia Górniczo-Hutnicza 